\title{
Ethics in nursing: categorization of legal processes
}

\author{
Ética em enfermagem: categorização de processos legais \\ Ética en enfermería: caracterización de procesos legales
}

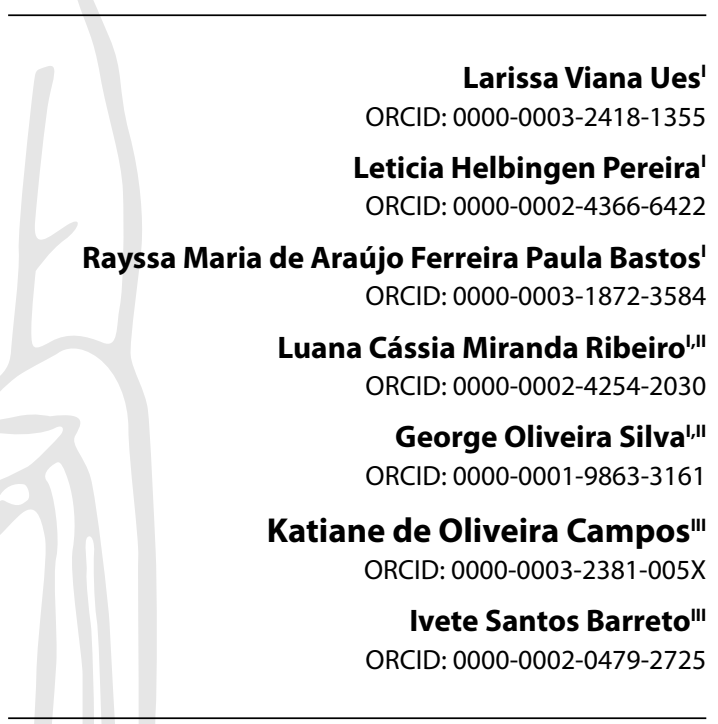

'Universidade Federal de Goiás. Goiânia, Goiás, Brazil. "Secretaria Municipal de Saúde de Goiânia. Goiânia, Goiás, Brazil.

"'Conselho Regional de Enfermagem. Goiânia, Goiás, Brazil.

How to cite this article:

Ues LV, Pereira LH, Bastos RMAFP, Ribeiro LCM, Silva GO,

Campos KO, et al. Ethics in nursing: categorization of legal processes. Rev Bras Enferm. 2022;75(3):e20210099. https://doi.org/10.1590/0034-7167-2021-0099

Corresponding author: Luana Cássia Miranda Ribeiro E-mail: luaufg@yahoo.com.br

EDITOR IN CHIEF: Antonio José de Almeida Filho ASSOCIATE EDITOR: Maria Itayra Padilha

Submission: $04-26-2021$

Approval: 07-30-2021

\section{RESUMO}

Objetivos: categorizar elementos fáticos dos processos ético-disciplinares de enfermagem no estado de Goiás. Métodos: estudo transversal, retrospectivo, com base em dados secundários obtidos de processos ético-disciplinares autuados no Conselho Regional de Enfermagem de Goiás (CorenGoiás) entre os anos de 2010 e 2019. Resultados: o maior número de processos instaurados foi nos anos 2013 e 2014, com maior frequência na capital do estado. A maioria adveio das Comissões de Ética de Enfermagem e das denúncias de ofício. O profissional mais denunciado foi o técnico de enfermagem, na faixa etária entre 31 e 40 anos, no início da carreira. $O$ tipo de denúncia mais comum referiu-se a exercer atribuições que não são competências da enfermagem. Conclusões: destaca-se a contribuição deste estudo para a ética profissional em enfermagem e a necessidade clara de consolidação dessas competências no profissional em formação e de educação permanente para aqueles que se encontram em exercício da profissão.

Descritores: Ética em Enfermagem; Processo Legal; Papel do Profissional de Enfermagem; Legislação de Enfermagem; Enfermagem.

\section{ABSTRACT}

Objectives: to categorize factual elements of ethical-disciplinary nursing lawsuits in the state of Goiás. Methods: cross-sectional, retrospective study, based on secondary data obtained from ethical-disciplinary lawsuits filed at the Regional Nursing Council of Goiás (Coren-Goiás) between the years 2010 and 2019. Results: the highest number of lawsuits filed was in 2013 and 2014, with a greater frequency in the state capital. The majority came from the Nursing Ethics Committees and ex-officio complaints. The professional with most complaints was the nursing technician, aged between 31 and 40 years old, at the beginning of their career The most common type of complaints referred to performing attributions that were not within the nursing competences. Conclusions: as a highlight are the contributions of this study to professional ethics in nursing and the clear need to consolidate these skills in nurses who are in training and in the continuous education for those already in the profession. Descriptors: Ethics in Nursing; Legal Process; Nurse's Role; Nursing Legislation; Nursing

\section{RESUMEN}

Objetivos: categorizar elementos fácticos de los procesos ético-disciplinarios de enfermería en Goiás. Métodos: estudio transversal, retrospectivo, basado en datos secundarios obtenidos de procesos ético-disciplinarios denunciados en el Consejo Regional de Enfermería de Goiás (CorenGoiás) entre 2010 y 2019. Resultados: el mayor número de procesos instaurados fue en 2013 y 2014, con mayor frecuencia en la capital del estado. La mayoría advino de las Comisiones de Ética de Enfermería y denuncias de oficio. El profesional más denunciado fue el técnico de enfermería, en la franja etaria entre 31 y 40 años, en inicio de carrera. El tipo de denuncia más común se referió a ejercer atribuciones que no son competencias de enfermería. Conclusiones: destacada la contribución de este estudio para la ética profesional en enfermería y necesidad clara de consolidación de esas competencias en el profesional en formación y educación permanente para aquellos que se encuentran en ejercicio de la profesión.

Descriptores: Ética en Enfermería; Proceso Legal; Rol de la Enfermera; Legislación de Enfermería; Enfermería. 


\section{INTRODUCTION}

In addition to the development of skills and competencies for clinical practice, nursing education requires the development of competencies based on the ethical-legal aspects of the profession $^{(1)}$. Thus, the professional's ethical training must be based on the construction of their scientific, technical, ethical, and legal knowledge in order to guarantee the best patient care, free from damage, complications, and ethical infractions ${ }^{(2)}$. However, the gap between theory and practice highlights the difficulties - faced daily by professionals - that interfere with the quality of the service provided and increase the probability of errors in care ${ }^{(3)}$.

In health care, errors can imply risks to patients and costs to institutions. It can be the result of an unintentional conduct, performed by any professional. Thus, it is essential for professionals to know the extent to which assistance can bring risks to the team, patients, and family ${ }^{(4)}$. Factors such as work overload, shortage of professionals, and deficient training are associated with errors in nursing care and may result in ethical violations ${ }^{(5)}$.

Ethical and disciplinary infractions consist of the professional's action, omission, or connivance against the ethical principles of his profession and non-compliance with the Nursing Professionals' Code of Ethics (NPCE), an ethical-legal device that guides professional practice, providing for rights, duties, and prohibitions, focusing on care for the individual and community, acting in the promotion, prevention, recovery, and rehabilitation ${ }^{(6)}$.

The Federal Nursing Council (Cofen) and the Regional Nursing Councils are public authorities regulated by Federal Law No. 5.905, of July 12,1973, responsible for identifying and prosecuting such infractions, which have been working to ensure protection of professional practice and the quality of care through inspection and investigation of ethical issues ${ }^{(7)}$.

Some studies carried out in the states of Ceará, São Paulo, and Santa Catarina have highlighted the theme in the last decade, suggesting a strong role of autarchies in the identification of infractions to the ethical-legal provisions of nursing and in the protection of professional practice ${ }^{(3,8-10)}$. However, regarding ethical violations and their associated factors, the national literature is still scarce.

Understanding the importance of the theme of a study of ethical processes in nursing and in order to understand the profile of ethical violations in the state of Goiás, it was established as a research question: "What are the factual elements disposed in the ethical processes filed in the Regional Council of Nursing in Goiás from 2010 to 2019 ?" It is understood by "factual elements", in this context, the description of the place and period of the complaints, the profile of the complainant, the profile of the accused, the types of complaint, the articles infringed, and the outcome of those processes.

In this sense, it is understood that knowledge about ethical processes can contribute to the practice of nursing professionals, leading to damage reduction and risk awareness during care, in addition to clarifying how the process of reporting and processing of an ethical process occurs.

\section{OBJECTIVES}

To categorize factual elements of ethical-disciplinary nursing lawsuits in the state of Goiás.

\section{METHODS}

\section{Ethical aspects}

In carrying out this study, information confidentiality and anonymity of those involved were respected, in addition to the rules regarding ethics in research involving human beings. As this is a documentary research with data from completed ethical-disciplinary lawsuits and with documents published through official vehicles, there was no need to submit the research to the Research Ethics Committee. However, the study was duly authorized by the Regional Nursing Council of Goiás and met the requirements of Law No. 12.527, of November 18, 2011; and Resolution 510, of April 7, 2016, of the National Health Council.

\section{Study design, period, and location}

Cross-sectional, retrospective study, guided by the STROBE Statement tool ${ }^{(11)}$. It was carried out using secondary data obtained from the records of all ethical nursing disciplinary processes filed at the Regional Nursing Council of Goiás (Coren Goiás). The study took place at the headquarters of Coren-Goiás, located in the city of Goiânia. Data collection occurred between October 2019 and January 2020, in the Ethical Processes and Committee Support Sector, where the files pertaining to the autarchy's ethical-disciplinary processes were stored. The time frame between 2010 and 2019 was established considering the implementation of the COFEN Resolution 370/2010, regarding the new Nursing Ethical Process Code ${ }^{(12)}$.

\section{Sample, inclusion and exclusion criteria}

The ethical-disciplinary processes of Coren-Goiás were used as a data source. The inclusion criteria were archived ethical lawsuits that had been filed and judged between 2010 and 2019, lawsuits that had already undergone admissibility, pre-trial, and/or judgment phases, had had a decision by the plenary of Coren-Goiás and syllabus' published through official vehicles. Ethical lawsuits in pre-trial phase were excluded.

\section{Study protocol}

The instrument was duly validated by a doctor nurse with expertise in nursing ethics and by a fiscal nurse with expertise in ethical-disciplinary lawsuits. It was prepared considering variables concerning the conduct of the ethical-disciplinary process, in accordance with the steps established in COFEN Resolution $370 / 2010$. For data extraction, after identifying the lawsuits to be included, the instrument was transferred to a form on Google Forms that had the following information: process number, process year, municipality, complainant's profile, defendant's profile, subject of complaint, process status, infringed articles, and outcome. As a way of maintaining information confidentiality, the sector coordinator provided instructions for completing the data collection instrument, safeguarding the identity of the complainants and defendants involved. 


\section{Analysis of results}

The factual elements involved were analyzed descriptively according to the characteristics of the ethical-disciplinary process in accordance with COFEN Resolution 370/2010; and were presented in the form of absolute and relative frequencies. The variables analyzed were municipalities, year of occurrence, complainant's profile, defendant's profile, types of complaints, outcome of proceedings, penalties applied, and NPCE infringed articles. The graphs were created in the statistical program $\mathrm{R}$ (version 4.0.3), using the ggplot $2^{(13)}$ package.

\section{RESULTS}

There were a total of 754 ethical-disciplinary procedures and lawsuits stored at the autarchy. Of these, 134 were tried and filed between 2010 and 2017. The lawsuits filed in 2018 and 2019 were in pre-trial phase, that is, not yet closed and filed. For this reason, even though the analysis was carried out until 2019, the last process included in the data collection was related to the year 2017. Of the 134, 15 lawsuits had multiple denounced; and three had more than one penalty applied to the offender.

Objectively, there was a need to account for ethical processes in two ways. The first considered the 134 lawsuits, equivalent to the actual number of files used in the study; this value was applied in the analysis of the variables: year of establishment, municipality of occurrence, profile of the complainant and type of complaint.

As for the variables related to the profile of the defendant: infringed articles of CEPE, outcome, and applied penalties, it was decided to individualize the lawsuits with multiple complainants. Thus, if a single process consisted of five defendants, five ethical lawsuits were counted. This action strategy allowed us to study case by case, as the professional categories, accusations, and penalties can be different.

Regarding the municipalities, there was an occurrence in 42 (17.07\%) of the 246 municipalities in the state of Goiás. The highest frequency of cases occurred in the capital, Goiânia, representing $34.33 \%(n=36)$ of the total, followed by Ceres $(10.45 \% ; n=14)$, Aparecida de Goiânia $(6.72 \% ; n=7)$, Anápolis $(4.48 \% ; n=6)$, and Estrela do Norte $(2.99 \% ; n=4)$. As for the year of establishment of ethical-disciplinary lawsuits, the year $2013(33.3 \% ; n=38)$ had the highest frequency, followed by $2014(16.6 \% ; n=19)$, and 2012 (15.7\%; $n=18$ ) (Figure 1).

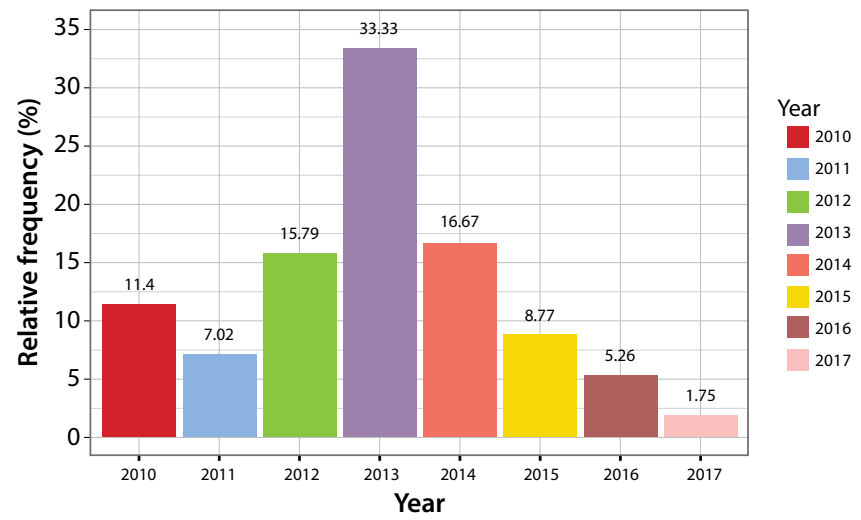

Figure 1 - Number of ethical-disciplinary cases filed in Coren-Goiás per year of filing, 2010-2017, Goiânia, Goiás, Brazil, 2020
Among the 134 complainants, 25 (18.66\%) were professionals from the nursing team, and 109 (81.34\%) were not part of the category. As for the complainants' profile, Nursing Ethics Committees and ex-officio complaints stood out as the most common, followed by complaints by family members, and other health team professionals as described in Table 1.

Table 1 - Ethical-disciplinary lawsuits complainants' profile filed in Coren-Goiás, 2010-2017, Goiânia, Goiás, Brazil, 2020

\begin{tabular}{lcc}
\hline Complainants' Profile & n & Frequency (\%) \\
\hline Nursing professional & & \\
Nurse & 7 & 28.0 \\
Nursing technician & 5 & 20.0 \\
Nursing Ethics Committee & 13 & 52.0 \\
Total & 25 & 100.0 \\
Non-Nursing professionals & & \\
Family & 8 & 7.3 \\
Other patient & 1 & 0.9 \\
Other professionals & 6 & 5.5 \\
Victim & 3 & 2.7 \\
Office staff & 85 & 77.9 \\
Public Ministry & 3 & 2.7 \\
City Hall & 1 & 0.9 \\
Health Surveillance & 1 & 0.9 \\
SUS National Audit Department & 1 & 0.9 \\
Total & 109 & 100.0 \\
\hline
\end{tabular}

There was a total of 182 denounced professionals, considering the nature of the 15 lawsuits that had multiple denounced parties. The profile of the reported professional was mostly of nursing technicians, aged between 31 and 40 years and with less than five years of professional registration, as shown in Table 2.

Table 2 - Profile of denounced professionals of the ethical-disciplinary lawsuits filed in Coren-Goiás, 2010-2017, Goiânia, Goiás, Brazil, 2020

\begin{tabular}{lcc}
\hline Denounced professionals' profile & $\mathbf{n}$ & Frequency (\%) \\
\hline Professional category & & \\
Nurse & 57 & 31.3 \\
Nursing technician & 106 & 58.2 \\
Nursing assistant & 19 & 10.5 \\
Total & 182 & 100.0 \\
Age (years) & & \\
$21-30$ & 45 & 24.7 \\
$31-40$ & 69 & 37.9 \\
$41-50$ & 43 & 23.6 \\
$51-60$ & 24 & 13.1 \\
$61-70$ & 1 & 0.5 \\
Total & 182 & 100.0 \\
Time in profession (years) & & \\
$<1-5$ & 101 & 55.4 \\
$6-10$ & 46 & 25.2 \\
$11-15$ & 20 & 10.9 \\
$16-20$ & 7 & 3.8 \\
$21-25$ & 5 & 2.7 \\
$26-30$ & 3 & 1.6 \\
Total & 182 & 100.0 \\
\hline
\end{tabular}

Complaints are classified by the Board into seven categories: Category 1 - Abuse/Aggression/Harassment/Offence; Category 2 - Inappropriate professional performance, professional misconduct in the work environment; Category 3 - Unethical conduct, associated with carrying out actions that are strictly prohibited for nursing professionals, including those involving crimes; Category 4 - Non-compliance with tax notification; Category 5 - Performing activities that are not under their responsibility, referring 
to the non-compliance with the legal attributions of nursing professionals; Category 6 - Irregular exercise of the profession, referring to performance without proper Council registration; and Category 7 - Negligence/Inexperience/Recklessness. Complaints by categories are shown in Figure 2 .

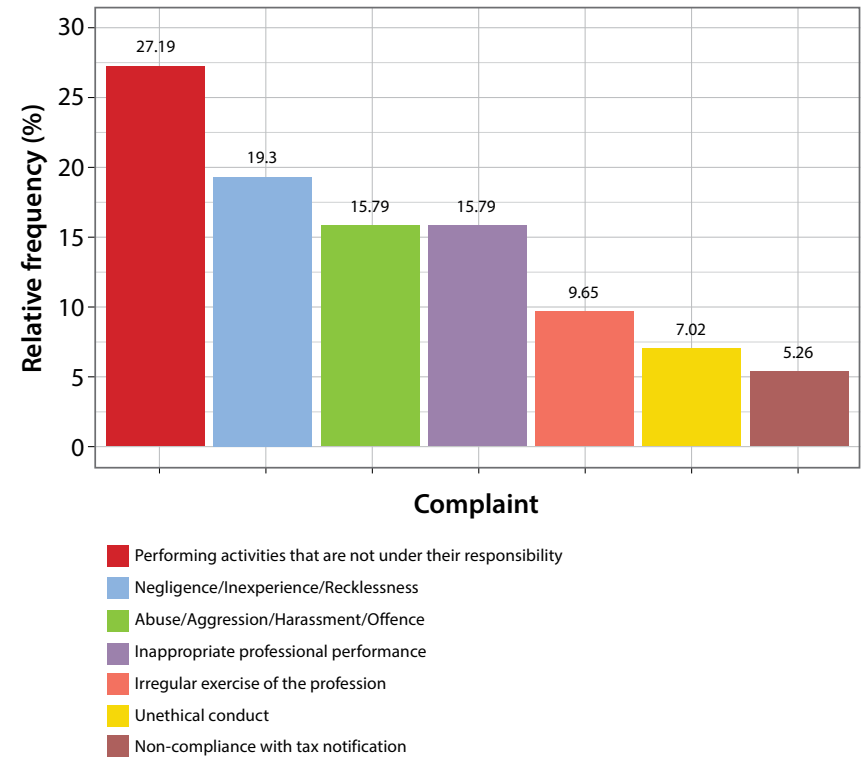

Figure 2 - Categorization of complaints of ethical-disciplinary lawsuits filed in Coren Goiás, 2010-2017, Goiânia, Goiás, Brazil, 2020

As for the outcomes of the 182 ethical lawsuits filed, 76 (41.8\%) were acquitted by the Plenary of the Council, 56 (30.8\%) had penalties applied. In 31 (17\%) cases, there was conciliation between the parties; in 13 (7.1\%), Conduct Adjustment Terms (CATs) were applied; five (2.7\%) had issues regarding deadlines; and one $(0.5 \%)$ process was appealed to Cofen.
As for penalties, a total of 61 were applied. There were 46 verbal warnings, eight censures, five suspensions, and two fines. Still, it is noteworthy that, in five cases, the accused received more than one penalty. Regarding the infringed articles, the last two Resolutions of Cofen that regulate the Code of Ethics were analyzed.

Of the total of 56 lawsuits in which penalties were applied, $40(89.3 \%)$ are based on Cofen Resolution No. $311 / 2007$ (duties: $55 \%, \mathrm{n}=22$; prohibitions: $45 \%, \mathrm{n}=18$ ) while the other lawsuits $(10.7 \% ; n=14)$ are based on Cofen Resolution No. 564/2017 (duties: $71.4 \%, n=10$; prohibitions: $28.6 \%, n=18$ ). The most infringed articles of each resolution are shown in Table 3.

\section{DISCUSSION}

During the collection period, the state of Goiás had 58,478 nursing professionals and, according to the Cadastro Nacional de Estabelecimentos de Saúde (CNES) [National Registry of Health Establishments], 11,244 health institutions, most of which were in Goiânia $(3,646)^{(14)}$. As this is the municipality with the most employment opportunities and with most nursing professionals, the number of complaints regarding them found in the results of this study is justified.

It was identified that the years 2012 to 2014 had higher frequencies of ethical-disciplinary lawsuits. This result is related to the activity of the inspection sector, which aims to ensure compliance with the ethical-legal provisions of the profession and quality assurance in health services ${ }^{(8)}$. It is a self-regulating system, in addition to being the core activity of professional councils, governed by Cofen Resolution No. 617/2019(15).

In Brazil, nursing inspection process challenges are anchored in the difficulties related to the nurses'lack of ethical-legal knowledge, deficient nursing dimensioning, and lack of a standardization in the inspection process ${ }^{(16-17)}$. Similarly, in the international context, divergences in regulatory laws suggest the political weakening

Table 3 - Infringed articles of the Nursing Professionals' Code of Ethics, Goiânia, Goiás, Brazil, 2020

\section{NPCE Infringed Articles}

n Frequency (\%)

Cofen Resolution n. ${ }^{\circ} 311 / 2007$

Art. 51 - Comply, within the established period, with the determinations and summons of the Federal and Regional Nursing Council.

Art. $5^{\circ}$ - Perform the profession with justice, commitment, equity, resoluteness, dignity, competence, responsibility, honesty, and loyalty.

Art. 12 - Assure the person, family, and community a nursing care that is free from damage resulting from malpractice, negligence, or recklessness.

Art. 13 - Carefully assess your technical, scientific, ethical, and legal competence and only accept duties or assignments when capable of a safe performance for yourself and others.

Art. 34 - To provoke, cooperate, collude or omitt any form of violence.

Others

Cofen Resolution n. ${ }^{\circ}$ 564/2017

Art. 81 Provide services that, by their nature, are the responsibility of another professional, except in an emergency, or that are expressly authorized by current legislation.

Art. 25 Base your relationships on law, prudence, respect, solidarity, and diversity of opinion and ideological position.

Art. 41 Provide nursing care without discrimination of any kind.

Others
23 
of the profession, in addition to opening a margin for greater tolerance to ethical violations, especially since, in some countries, more than one body carries out this regulatory process ${ }^{(18)}$.

As for the complainant, the Nursing Ethics Committees (NEC) stood out, which, since 2018, must be present in every institution with more than 50 nursing professionals. Its role is to represent the Regional Nursing Council in the services, and they have an educational, advisory, conciliation, guidance, and surveillance function in the professional ethical exercise ${ }^{(19)}$. Therefore, the performance of the NECs consisted of receiving complaints related to professional practice and forwarding them to Coren for further investigation.

A recent integrative review analyzed the insertion of nurses in NECs in national and international studies. The results showed that nursing professionals recognize the importance of commissions, and for such insertion, specific knowledge, skills, and attitudes are required to work in the area. Greater contact between NECs and professionals through educational activities can contribute to greater bonding between professionals, service, and regulatory bodies ${ }^{(20)}$. Currently, the state of Goiás has 62 NECs, which shows the strengthening of these instances as representatives of the Council.

Ex-officio denunciations also constituted an important quantity; represented the complaints arising from inspection processes or other means of investigation requested by the presidency of the municipality ${ }^{(12)}$. Similar to a related study ${ }^{(10)}$, complaints made by family members had a low frequency, suggesting that family members and the victim themselves are unaware of the channels available to carry them out.

Nursing technicians were the most reported professionals. In Goiás, most registered professionals are from this category, which is similar to other scenarios ${ }^{(21)}$. This data differs from the results found by other studies ${ }^{(3,10)}$, in which the nurse was appointed as the most reported professional. Differently, in São Paulo, the nursing assistant profession received a greater number of lawsuits ${ }^{(9)}$.

As for the age group, most offenders were between 31 and 40 years old, results like those found in São Paulo; this is due to professional inexperience and career insecurity, factors observed that can compromise direct care ${ }^{(9)}$. Other results reveal that professionals in the beginning of their career committed more infractions in care, corresponding to $55.49 \%$ of cases, which was corroborated by another study ${ }^{(21)}$.

Nevertheless, it is noteworthy that eight (4\%) denounced parties had more than 20 years of professional registration in the profession, a fact that draws attention because this time is close to the number of years required for retirement and reinforces the need to promote permanent education ${ }^{(22)}$. This is because, with a trained and involved team, it is possible that there will be a reduction in the number of professionals who commit ethical violations. Such factors lead us to reflect on the quality of training regarding the teaching of professional ethics and the need to encourage the development of ethical competences during the training period.

Furthermore, the growing number of ethical occurrences can be explained by factors such as inadequate nursing staff dimensioning, work overload, and deficient training ${ }^{(16,21)}$. However, this does not exempt the professional from his responsibility to ensure that the care he provides is free from negligence-inflicted damage, malpractice, and imprudence ${ }^{(6)}$.

In the categorization of the types of complaint, "performing duties that are not your responsibility" was highlighted, in line with the results of a study carried out in Ceará(3), in which it is highlighted that, with inadequate nursing staff dimensioning, professionals are coerced into carrying out activities that are not within their competence.

However, it is essential to point out that the NPCE supports the professional, reinforcing that he/she should only perform attributions of their competence, which includes the technique, scientific knowledge, and aptitude in the performance of activities. Thus, it is the nursing professional's duty to provide harm-free care to the patient, family, or community, attitudes that are strengthened during training ${ }^{(1,4)}$.

The results of the present study pointed to a high frequency of ethical disciplinary proceedings resulting in acquittal for not characterizing as ethical infractions. The number of lawsuits with ethical violations was also significant, with greater application of verbal warning, followed by censorship, suspension, and fine. The profile of the penalties applied shows the educational and non-punitive nature adopted by the autarchy in the judgment of nursing professionals in Goiás, results that corroborate other studies $^{(3,10)}$.

This educational role is demonstrated by the number of lawsuits in which there were conciliations or CAT signatures. These provisions are based on the Ethical Process Code, which determines that, in the absence of death resulting from the infraction and upon evaluation by the Reporting Councilor of the ethical-disciplinary process, a hearing of the parties is held for conciliation or adjustment of conduct. It should be considered that conciliation is a benefit that is granted to the professional only once ${ }^{(12)}$.

The most infringed article of the previous NPCE version concerns the nursing professional's duty to comply with the determinations and summons of the council within the established period, which also applies to the inspection process, with which the professional has the obligation to collaborate ${ }^{(23)}$. The frequency of this infraction and the non-observance of this data in other studies suggest that not updating the information of professionals in the council can make it difficult to locate them for communication if necessary. Furthermore, in general, professionals do not always understand the role of the council and the importance of supervision as a way to protect the quality of care ${ }^{(24)}$.

As for the current NPCE, the most infringed article consists of a prohibition and is related to the performance of activities that are not under the responsibility of the nursing professional, a result that ratifies a related study ${ }^{(3)}$ in which illegal and irregular exercise of the profession is addressed. This infraction is configured as a crime typified in article 47 of the Criminal Misdemeanor Law: it states that, in order to exercise any profession, legal conditions must be met ${ }^{(10)}$.

Some studies ${ }^{(3,9)}$ address the existence of situations in which nursing professionals, in the absence of other professionals, are compelled to perform activities that are not under their responsibility, exposing professionals and patients to situations of insecurity and risk. In these cases, the professional is supported 
by the NCPE to refuse to provide such assistance, except in emergency cases as stated in the article itself.

Thus, the high frequency of ethical infractions observed in this study reflects the low adherence of professionals to NCPE, which suggests a deficit in the knowledge of ethical-legal aspects of the profession $^{(25)}$. Therefore, to reduce the gap between professional practice and compliance with nursing regulations, there is a need to implement strategies such as the implementation of $\mathrm{NECS}^{(20)}$ and the development of ethical competences during the training period ${ }^{(26)}$.

\section{Study limitations}

The study presented as limitations: its descriptive character, which did not allow the identification of cause-and-consequence relationships; and the limited literature on the subject. However, it is believed that the results found may be fundamental for the characterization of ethical violations and the formulation of strategies aimed at reducing such injuries.

\section{Contributions to the Nursing Area}

This study helps to understand the nursing practice scenario, the factors that permeate complaints, and the occurrence of ethical violations by these professionals. Through this, it helps to promote the quality of nursing care to the population, a care free from malpractice, recklessness, and negligence damage.

\section{CONCLUSIONS}

With the categorization of the data, it was possible to understand the factual elements that permeate the ethical lawsuits instituted in Goiás in recent years, with emphasis on lawsuits arising from inspection complaints, with a high frequency of infractions committed predominantly by professionals in the beginning of their careers, nursing technicians, especially in activities that are not within its competence or that involve negligence, malpractice, or recklessness.

The study proved to be innovative for presenting nuances not yet available in previous studies and for contributing to the joint construction of the study of deontology in nursing in the country. It is noteworthy that this work, indirectly, reinforces the need to rethink the development of ethical-legal skills in nursing education, an important gap in professional practice.

It is important to emphasize that adverse events can happen to any professional at any time. For this reason, a culture of safety in care must be promoted, through regulatory legislation, institutional protocols, technical training of the nursing and health team, and protection for exercising the profession.

The protection of the professional practice is a role that belongs not only to institutions, but also to professionals, through social and professional commitment, individual and collective awareness, and the search for scientific and political improvement in order to meet the population's health needs. In this context, the role of continuing education in building such commitment is fundamental.

\section{REFERENCES}

1. Boozaripour M, Abbaszadeh A, Shahriari M, Borhani F. Ethical values in nurse education perceived by students and educators. Nurs Ethics. 2017;25(2):253-63. https://doi.org/10.1177/0969733017707009

2. Yeom H-A, Ahn S-H, Kim S-J. Effects of ethics education on moral sensitivity of nursing students. Nurs Ethics. 2016;24(6):644-52. https://doi. org/10.1177/0969733015622060

3. Mendonça FAC, Menezes MV, Amorim SC, de Morais FDM, Feitosa EMN, Lacerda CMM. Processo ético de enfermagem no estado do ceará: reflexão para prática profissional. Enferm Foco. 2017;8(2). https://doi.org/10.21675/2357-707X.2017.v8.n2.735

4. World Health Organization (WHO). Patient safety: making health care safer [Internet]. Geneva: World Health Organization; 2017 [cited 2020 Dec 16]. Available from: https://apps.who.int/iris/handle/10665/255507

5. Duarte SCM, Stipp MAC, Cardoso MMVN, Büscher A. Patient safety: understanding human error in intensive nursing care. Rev Esc Enferm USP. 2018;52:e0340. https://doi.org/10.1590/s1980-220x2017042203406

6. Conselho Federal de Enfermagem (Cofen). Resolução COFEN no 567 de 06 de dezembro de 2017 (BR). Aprovar o novo Código de Ética dos Profissionais de Enfermagem. Brasília: COFEN; 2017.

7. Presidência da República (BR). Lei Federal n.o 5.905, de 12 de julho de 1973. Dispõe sobre a criação dos Conselhos Federal e Regionais de Enfermagem e dá outras providências [Internet]. Brasília: Diário Oficial da União; 1973[cited 2020 Dec 16]. Available from: http://www. planalto.gov.br/ccivil_03/leis/15905.htm

8. Lima LMN, Andrade SR, Ruoff AB, Albuquerque GL. Decisões dos Conselhos de Enfermagem no Brasil: uma pesquisa documental. Enferm Foco. 2018;8(4):42-8. https://doi.org/10.21675/2357-707X.2017.v8.n4.1328

9. Mattozinho FCB, Freitas GF. Ocorrências éticas de enfermagem no Estado de São Paulo: descrição fática. Acta Paul Enferm. 2015;28:593-600. https://doi.org/10.1590/1982-0194201500097

10. Schneider DG, Ramos FRS. Nursing ethical processes in the State of Santa Catarina: characterization of factual elements. Rev Latino-Am Enfermagem. 2012;20:744-52. https://doi.org/10.1590/s0104-11692012000400015

11. von Elm E, Altman DG, Egger M, Pocock SJ, Gøtzsche PC, Vandenbroucke JP; STROBE Initiative. The Strengthening the Reporting of Observational Studies in Epidemiology (STROBE) statement: guidelines for reporting observational studies. PLoS Med. $2007 ; 4(10):$ e296. https://doi.org/10.1371/journal.pmed.0040296

12. Conselho Federal de Enfermagem (Cofen). Resolução COFEN no 370 de 03 de agosto 2010. Aprovar o Código de Processo Ético dos 
Conselhos de Enfermagem. Brasília: Conselho Regional de Enfermagem; 2010.

13. Wickham H. Ggplot2: elegant graphics for data analysis [Internet]. Springer-Verlag New York; 2016 [cited 2020 Nov 27]. Available from: http://ggplot2.org

14. Ministério da Saúde (BR). Cadastro Nacional de Estabelecimentos de Saúde (CNES). [Internet]. 2020[cited 2020 Dec 16]. Available from: http://www2.datasus.gov.br/DATASUS/index.php?area=0204

15. Conselho Federal de Enfermagem (Cofen). Resolução COFEN no 617 de 21 de outubro de 2019. Brasília: Conselho Federal de Enfermagem; 2019.

16. Silveira LR, Souza Ramos FR. Os maiores desafios e dificuldades para realizar o trabalho de fiscal do COREN/SC. Enferm Foco. 2014;5(1/2):336. https://doi.org/10.21675/2357-707X.2014.v5.n1/2.602

17. Pereira LH, Rodrigues ACC, Cavalcante RGF, Santos PT, Ribeiro LCM. Fiscalização do exercício profissional na área da saúde. Enferm Foco. 2020;10(6). Available from: https://doi.org/10.21675/2357-707X.2019.v10.n6.2253

18. Duncan S, Thorne S, Rodney P. Evolving trends in nurse regulation: what are the policy impacts for nursing's social mandate? Nurs Inq. 2014;22(1):27-38. https://doi.org/10.1111/nin.12087

19. Conselho Federal de Enfermagem (Cofen). Resolução COFEN no 593 de 09 de novembro de 2018. Normatizar a criação e funcionamento das Comissões de Ética de Enfermagem-CEE nas Instituições com Serviço de Enfermagem. 2018.

20. Brito GMG, Santa Rosa DO. Nurses performance in clinical ethics committees and commissions: an integrative review. Nurs Ethics. 2017;26(3):688-99. https://doi.org/10.1177/0969733017724611

21. Silva ALNV, Candido MCFS, Duarte SJH, Sampaio ATL, Santos RM. Relação entre tempo de exercício profissional e ocorrências éticas em enfermagem. Rev Enferm UERJ. 2018;26. https://doi.org/10.12957/reuerj.2018.23058

22. Tibola TSA, Cordeiro ALPC, Stacciarini TSG, Engel RH, Costa DG, Haas VJ. Fatores que influenciam a participação dos profissionais de enfermagem na educação permanente em hospital público. Enferm Foco. 2019;10(2):125-30. https://doi.org/10.21675/2357-707X.2019. v10.n2.2044

23. Conselho Federal de Enfermagem (Cofen). Resolução COFEN no 311 de 17 de fevereiro de 2007. Aprova o Código de Ética dos Profissionais de Enfermagem. 2007.

24. Nascimento WS, Costa IMB, Maia AMO, Ferreira TMC, Ribeiro GS, Lucena ALR. Percepção dos Profissionais de Enfermagem sobre o seu Conselho de classe. Enferm Foco. 2020;10(6). https://doi.org/10.21675/2357-707X.2019.v10.n6.1952

25. Beykmirza R, Nikfarid L, Atashzadeh-Shoorideh F, Nasiri M. Nursing adherence to ethical codes in pediatric oncology wards. Nurs Ethics. 2017;26(3):924-36. https://doi.org/10.1177/0969733017730683

26. Poorchangizi B, Borhani F, Abbaszadeh A, Mirzaee M, Farokhzadian J. The importance of professional values from nursing students' perspective. BMC Nurs. 2019;18(1):26. https://doi.org/10.1186/s12912-019-0351-1 